\title{
Dampak Pendekatan Matriks Enam Sel untuk Meningkatkan Kemampuan Pembuktian Calon Guru Matematika
}

\author{
Kimura Patar Tamba \\ Program Studi Pendidikan Matematika, Fakultas Ilmu Pendidikan, Universitas Pelita Harapan \\ Boulevard 1100, Klp. Dua, Kec. Klp. Dua, Tangerang, Banten \\ kimura.tamba@uph.edu
}

\begin{abstract}
The six-cell matrix is a framework for understanding the logical structure of quantified mathematical statements. The purpose of this study was to analyze the impact of the use of a six-cell matrix in improving the ability of proving statements in the office of prospective mathematics teachers. This study used a preexperimental design with a pre-test and post-test in one non-randomized group. The research sample was 35 mathematics teacher candidates. The pre-test and post-test data collection used test questions consisting of six quantified statement. Data were analyzed using descriptive statistics and the Wilcoxon signed ranks test. The results showed that the use of a six-cell matrix in learning could improve the pre-service mathematics teachers' mathematical proof ability. In particular, pre-service mathematics teachers' mathematical proof ability increases significantly in existentially quantified statement.
\end{abstract}

Keywords: Quantified Statement, Proof, Six Cell Matrix

\begin{abstract}
Abstrak
Matriks enam sel merupakan kerangka dalam memahami struktur logika dari pernyataan matematika berkuantor. Tujuan penelitian ini adalah untuk menganalisis dampak penggunaan matriks enam sel dalam meningkatkan kemampuan pembuktian pernyataan berkuantor calon guru matematika. Penelitian ini menggunakan desain pre-experimental dengan pre-test dan post-test pada satu kelompok tidak acak. Sampel penelitian ini adalah 35 calon guru matematika. Pengumpulan data pre-test dan post-test menggunakan soal tes yang terdiri dari enam pernyataan matematika berkuantor. Data dianalisis dengan menggunakan statistik deskriptif dan uji Wilcoxon signed ranks. Hasil penelitian menunjukkan bahwa penggunaan matriks enam sel dalam pembelajaran dapat meningkatkan kemampuan pembuktian pernyataan berkuantor calon guru matematika. Secara khusus, kemampuan pembuktian calon guru matematika meningkat secara signifikan pada pernyataan berkuantor eksistensial.
\end{abstract}

Kata kunci: Pernyataan Berkuantor, Pembuktian, Matriks Enam Sel

Copyright (c) 2021 Kimura Patar Tamba

$\triangle$ Corresponding author: Kimura Patar Tamba

Email Address: kimura.tamba@uph.edu (Cluster Permata Karawaci, Curug, Tangerang)

Received tanggal bulan tahun, Accepted tanggal bulan tahun, Published tanggal bulan tahun

\section{PENDAHULUAN}

Pembuktian adalah bagian penting dalam matematika dan tidak dapat dipisahkan dari matematika (Hanna \& de Villiers, 2008; Miyazaki et al., 2017; Pablo et al., 2012). Bahkan pembuktian merupakan komponen esensial dalam bermatematika, mengkomunikasikan dan memahami matematika (Stylianou et al., 2015). Oleh karena itu, berbagai komunitas matematikawan dan pendidikan matematika mengusulkan bahwa belajar pembuktian adalah tujuan utama dari belajar-mengajar matematika (NCTM, 2000; Stylianides \& Stylianides, 2017; Stylianou et al., 2015). Bahkan pembuktian disarankan sudah dimulai dari tingkat pendidikan yang paling rendah (sekolah dasar).

Namun berbagai penelitian menunjukkan siswa dan mahasiswa mengalami kesulitan yang 
akhirnya menghasilkan kesalahan-kesalahan dalam pembuktian, seperti kesalahan logika, kesalahan memilih metode pembuktian bahkan kesalahan memahami struktur pernyataan (De Villiers, 2004; Herutomo, 2019; Kristianto et al., 2019; Sari et al., 2018; Stavrou, 2014). Salah satu bentuk pernyataan yang masih sulit untuk dibuktikan oleh siswa dan mahasiswa (termasuk calon guru matematika) adalah pernyataan berkuantor. Hal ini ditunjukkan oleh berbagai penelitian yang mengungkapkan bahwa mahasiswa cenderung salah dalam memahami aturan kebergantungan dalam membuktikan pernyataan berkuantor ganda (PiatekJimenez, 2010), kesulitan memahami sintaks dan semantik dari pernyataan berkuantor (Dawkins, 2017; Dawkins \& Roh, 2016, 2020; Dubinsky \& Yiparaki, 2001). Berbagai penelitian tersebut mengungkapkan bahwa kemampuan pembuktian calon guru matematika masih rendah.

Fakta terdapatnya kesalahan-kesalahan yang dilakukan oleh mahasiswa (khususnya calon guru matematika) dalam membuktikan pernyataan berkuantor memerlukan pendekatan tertentu untuk menyelesaikannya. Hal ini penting karena berbagai konsep matematika dinyatakan dalam bentuk pernyataan berkuantor (Morgan, 2020; Ngansop, 2018; Sellers et al., 2017; Stewart, 2012). Berbagai penelitian mengenai kesalahan pada pembuktian dengan pernyataan berkuantor di atas memberikan rekomendasi pentingnya pemahaman mengenai struktur logika dari pernyataan tersebut (Dawkins, 2017; Dawkins \& Roh, 2016, 2020; Dubinsky \& Yiparaki, 2001; Piatek-Jimenez, 2010). Salah satu pendekatan yang dapat digunakan dalam mendorong pemahaman mengenai struktur logika dari pernyataan berkuantor adalah penggunaan matriks enam sel (the six-cell matrix) (Levenson et al., 2012; Tabach et al., 2012; Tamba, 2020). Matriks enam sel diperkenalkan oleh Tabach et al. (2012) untuk mengeksplorasi struktur logika pernyataan berkuantor dalam konteks pembuktian. Melalui matriks enam sel ini, Tabach et al. (2012) mengungkapkan tiga dimensi dalam struktur logika pernyataan berkuantor. Pertama, kuantifiernya (universal atau eksistensial); kedua, predikatnya (selalu benar, kadang-kadang benar atau tidak pernah benar); dan ketiga, validitasnya (valid atau tidak valid). Berdasarkan komposisi ketiga dimensi ini, pernyataan berkuantor dapat dinyatakan dalam matriks enam sel seperti tabel 1. Matriks enam sel dapat digunakan sebagai pendekatan pembelajaran, alat mengembangkan interaksi, sebagai materi pembelajaran bermakna (Levenson et al., 2012), kerangka menguji pengetahuan (Tabach, Barkai, et al., 2010; Tabach, Levenson, et al., 2010; Tamba, 2020). 
Tabel 1. Matriks Enam Sel

\begin{tabular}{|l|l|l|l|}
\hline \multirow{2}{*}{ Kuantor } & \multicolumn{3}{|c|}{ Predikat } \\
\cline { 2 - 4 } & Selalu Benar & Tidak Selalu Benar & Tidak Pernah Benar \\
\hline Universal & sel 1 & sel 2 & sel 3 \\
& Pernyataan benar & Pernyataan salah & Pernyataan salah \\
& Bukti general & Bukti counter example & Bukti general, counter example \\
\hline Eksistensial & sel 4 & sel 5 & sel 6 \\
& Pernyataan benar & Pernyataan benar & Pernyataan salah \\
& Bukti general, example & Bukti example & Bukti general \\
\hline
\end{tabular}

Dari berbagai penelitian sebelumnya belum ada yang mencoba menggunakan pendekatan matriks enam sel dalam meningkatkan kemampuan pembuktian pernyataan berkuantor pada calon guru matematika (Dawkins, 2017; Dawkins \& Roh, 2016, 2020; Dubinsky \& Yiparaki, 2001). Begitu juga dalam konteks penggunaan matriks enam sel, penelitian sebelumnya belum melihat penggunaan matriks enam sel ini dalam meningkatkan kemampuan pembuktian pernyataan berkuantor pada calon guru matematika (Levenson et al., 2012; Tabach et al., 2012; Tamba, 2020).

Penelitian ini bertujuan untuk menganalisis dampak penggunaan matriks enam sel dalam meningkatkan kemampuan pembuktian pernyataan berkuantor calon guru matematika. Secara detail, penelitian ini akan menguji dan menganalisis perbedaan kemampuan pembuktian calon guru matematika sebelum dan sesudah penerapan matriks enam sel.

\section{METODE}

Penelitian ini adalah penelitian kuantitatif menggunakan pre-experimental designs dengan pre-test dan post-test pada satu kelompok tidak random (nonrandomized one group pretest-posttest design) (Creswell, 2012) seperti yang terlihat pada tabel 2. Validasi internal dan eksternal dari penelitian eksperimental ini mengkonfirmasi hasil penelitian merupakan hasil dari perlakuan penerapan matriks enam sel. Sampel penelitian ini adalah 35 orang calon guru matematika yang mengikuti mata kuliah logika dan teori himpunan. Pre-test dilakukan sebelum pelaksanaan pembelajaran dengan pendekatan matriks enam sel dan post-test sesudahnya.

Tabel 2. Design Penelitian

\begin{tabular}{|c|c|c|}
\hline Pre-test & Perlakuan & Post-test \\
\hline$Y_{1}$ & $X$ & $Y_{2}$ \\
\hline
\end{tabular}

Keterangan:

$\boldsymbol{Y}_{\mathbf{1}}=$ pre-test kemampuan pembuktian

$Y_{2}=$ post-test kemampuan pembuktian

$X=$ perlakuan berupa pendekatan matriks enam sel 
Pelaksanaan penerapan matriks enam sel dalam pembelajaran dilakukan dengan pertamatama dosen mengajukan enam permasalahan pembuktian pernyataan berkuantor yang telah disusun berdasarkan matriks enam sel kepada calon guru matematika. Secara mandiri kemudian menyelesaikan pembuktian secara mandiri, setelah bekerja mandiri calon guru berdiskusi dengan kelompok berdasarkan hasil pekerjaannya. Setelah itu, dosen memulai diskusi kelas. Pada diskusi kelas ini, hasil pekerjaan mandiri maupun diskusi kelompok diminta untuk dipresentasikan. Setelah itu, dosen membawa diskusi dengan menggunakan matriks enam sel sebagai kerangka diskusi. Alur diskusi mengikuti pendekatan yang dilakukan oleh Levenson et al. (2012), yaitu alur berikut mengamati koneksi logis (noticing connections), diskusi fokus pada validitas dan kuantifikasi (focusing on validity and quantifiers), menguraikan pernyataan matematika berdasarkan kuantor dan predikat (decomposing a mathematical statement into its quantifier and predicate) lalu diakhiri pada diskusi metode pembuktian (methods of proofs) berdasarkan penguraian pada matriks enam sel didiskusi sebelumnya.

Instumen yang digunakan dalam penelitian ini adalah tes yang memuat permasalahan pembuktian enam pernyataan berkuantor. Ada dua instrument tes yang digunakan pada penelitian ini yaitu pre-test dan post-test. Baik pre-test maupun post-test masing-masing memuat permasalahan pembuktian untuk enam pernyataan berkuantor (Tabel 3). Pernyataan berkuantor pada pre-test maupun post-test dapat dibagi dalam dua kategori yaitu pernyataan berkuantor universal (soal no 1, 2 dan 3) dan berkuantor eksistensial (soal no 4, 5, dan 6). Konten yang digunakan dalam setiap pernyataan berkuantor pada pre-test maupun post-test adalah topik teori bilangan. Topik ini dipilih karena partisipan sudah lulus mata kuliah teori bilangan. Untuk pre-test dan post-test diberikan waktu 120 menit untuk penyelesaiannya.

Tabel 3. Instrumen Penelitian

\begin{tabular}{|c|l|l|}
\hline Perny. ke- & \multicolumn{1}{|c|}{ Pre-test } & \multicolumn{1}{c|}{ Pos-test } \\
\hline 1 & $\begin{array}{l}\text { Jumlah dari lima bilangan asli yang } \\
\text { berurutan habis dibagi } 5 .\end{array}$ & $\begin{array}{l}\text { Semua bilang bulat positif } m, \text { jika } a \equiv \\
b(\bmod m) \operatorname{maka} a+c \equiv b+c(\bmod m)\end{array}$ \\
\hline 2 & $\begin{array}{l}\text { Jumlah dari tiga bilangan asli yang } \\
\text { berurutan habis dibagi } 6 .\end{array}$ & $\begin{array}{l}\text { Semua bilang bulat positif } m,(a+ \\
b) \bmod m=(a \bmod m)+(b \bmod m)\end{array}$ \\
\hline 3 & $\begin{array}{l}\text { Jumlah dari empat bilangan asli } \\
\text { yang berurutan habis dibagi 4 }\end{array}$ & $\begin{array}{l}\text { Semua bilangan positif } m, a \equiv b(\bmod m) \\
\text { maka } a-c \not b b-c(\bmod m)\end{array}$ \\
\hline 4 & $\begin{array}{l}\text { Ada lima bilangan asli berurutan } \\
\text { yang jumlahnya habis dibagi } 5\end{array}$ & $\begin{array}{l}\text { Ada bilangan bulat positif } m \text {, berlaku jika } \\
a \equiv b(\bmod m) \text { maka } a c \equiv b c(\bmod m)\end{array}$ \\
\hline 5 & $\begin{array}{l}\text { Ada tiga bilangan asli berurutan } \\
\text { yang jumlahnya habis dibagi } 6\end{array}$ & $\begin{array}{l}\text { Ada bilang bulat positif } m,(a b) \bmod m= \\
(a \bmod m)(b \bmod m)\end{array}$ \\
\hline
\end{tabular}




\begin{tabular}{|l|l|l|}
\hline 6 & $\begin{array}{l}\text { Ada empat bilangan asli berurutan } \\
\text { yang jumlahnya habis dibagi } 4\end{array}$ & $\begin{array}{l}\text { Ada bilangan positif } m, a \equiv b(\bmod m) \\
\text { maka } a-c \equiv b-c(\bmod m)\end{array}$ \\
\hline
\end{tabular}

Hasil pre-test dan post-test diskor dengan menggunakan kerangka penskoran pembuktian dari Healy \& Hoyles (2000) dengan skala 0-3. Skor 0 berarti "tidak ada dasar untuk konstruksi bukti yang benar" artinya pembuktian dan informasi yang diberikan oleh calon guru tidak memiliki dasar logika yang benar dan relevan. Skor 1 berarti "tidak ada bagian pembuktian tetapi menyajikan informasi yang benar dan relevan". Skor 2 berarti "terdapat bukti yang tidak lengkap (sebagian), beberapa alasan dihilangkan". Skor 3 berarti "bukti lengkap". Kerangka penskoran ini dilakukan untuk keenam pernyataan pada masing-masing pre-test dan post-test. Dengan demikian skor maksimum untuk pre tes dan pos tes adalah 18.

Analisis data dilakukan dengan menggunakan statistik inferensial dengan metode analisis perbedaan rata-rata. Penelitian ini menggunakan uji-t sampel berpasangan dalam menganalisis perbedaan rata-rata. Namun jika data tidak memenuhi uji asumsi klasik (normalitas dan homogenitas) maka analisis dilakukan menggunakan uji Wilcoxon signed ranks. Analisis dilakukan dengan bantuan software SPSS 20.0.

\section{HASIL DAN DISKUSI}

Hasil analisis deskriptif kemampuan pembuktian pernyataan matematika berkuantor terlihat pada tabel 4. Rata-rata skor total kemampuan pembuktian pernyataan berkuantor pada pre-test sebesar 15,00, sementara pada post-test sebesar 16,97. Jika dibandingkan antara skor total pre-test dan post-test terdapat kenaikan kemampuan pembuktian pernyataan berkuantor sebesar 1,97. Sementara berdasarkan butir soal. Rata-rata skor kemampuan pembuktian calon guru matematika meningkat dari pre-test ke post-test untuk soal nomor 1 (pernyataan berkuantor universal, predikat selalu benar), soal nomor 3 (pernyataan berkuantor universal, predikat selalu salah), soal nomor 4 (pernyataan berkuantor eksistensial, predikat selalu benar), nomor 5 (pernyataan berkuantor eksistensial, predikat tidak selalu benar) dan nomor 6 (pernyataan berkuantor eksistensial, predikat selalu salah). Sementara untuk soal nomor 2, rata-rata skor kemampuan pembuktian tidak mengalami perubahan. Artinya secara umum baik untuk pernyataan berkuantor universal maupun berkuantor eksistensial, rata-rata skor kemampuan pembuktian calon guru matematika mengalami peningkatan dari pre-test ke post-test. 
Dampak Pendekatan Matriks Enam Sel untuk Meningkatkan Kemampuan Pembuktian Calon Guru Matematika, Kimura

Tabel 4. Deskriptif kemampuan pembuktian pernyataan berkuantor pre-test dan post-test.

\begin{tabular}{|c|r|r|r|r|r|r|r|r|}
\hline & \multicolumn{2}{|c|}{ Min. } & \multicolumn{2}{c|}{ Max. } & \multicolumn{2}{c|}{ Mean } & \multicolumn{2}{c|}{ Std.Dev. } \\
\cline { 2 - 10 } & \multicolumn{1}{|c|}{ Pre } & \multicolumn{1}{c|}{ Post } & \multicolumn{1}{c|}{ Pre } & \multicolumn{1}{c|}{ Post } & \multicolumn{1}{c|}{ Pre } & \multicolumn{1}{c|}{ Post } & \multicolumn{1}{c|}{ Pre } & \multicolumn{1}{c|}{ Post } \\
\hline Skor Total & \multicolumn{1}{|c|}{7,00} & 11,00 & 23,00 & 22,00 & 15,00 & 16,97 & 3,14 & 2,32 \\
\hline Soal No 1 & 2,00 & 2,00 & 4,00 & 4,00 & 3,03 & 3,20 & 0,66 & 0,47 \\
\hline Skor No 2 & 1,00 & 2,00 & 4,00 & 4,00 & 2,20 & 2,20 & 0,58 & 0,47 \\
\hline Skor No 3 & 0,00 & 0,00 & 4,00 & 4,00 & 2,77 & 2,89 & 0,91 & 0,68 \\
\hline Skor No 4 & 0,00 & 0,00 & 4,00 & 4,00 & 2,60 & 2,91 & 0,95 & 0,70 \\
\hline Skor No 5 & 0,00 & 2,00 & 4,00 & 4,00 & 2,31 & 2,86 & 0,83 & 0,60 \\
\hline Skor No 6 & 0,00 & 2,00 & 4,00 & 4,00 & 2,09 & 2,91 & 0,95 & 0,51 \\
\hline
\end{tabular}

Hasil uji asumsi normalitas dengan tes Shapiro-Wilk untuk skor kemampuan pembuktian pernyataan berkuantor baik pre tes maupun pos tes menunjukkan hanya skor total pre tes yang berdistribusi normal $(T 3=0,97 ; p=0,51>0,05)$. Sementara data lainnya tidak berdistribusi normal (nilai T3 diantara 0,48-0,97; $p<0,05$ ). Oleh karena itu, uji perbedaan skor pre-test dan post-test dilakukan dengan menggunakan uji Wilcoxon signed ranks.

Hasil uji Wilcoxon signed ranks terlihat pada Tabel 5. Hasil uji Wilcoxon signed ranks ini menunjukkan bahwa secara total terdapat perbedaan signifikan kemampuan pembuktian pernyataan berkuantor antara pre-test dan post-test $(Z=-2,69 ; p=0,007<0,05)$. Artinya dapat diungkapkan bahwa terdapat peningkatan signifikan rata-rata skor total kemampuan pre-test dan post-test (Tabel 4). Dengan demikian, penggunaan matriks enam sel dapat meningkatkan kemampuan pembuktian pernyataan berkuantor calon guru matematika.

Tabel 5. Hasil Uji Wilcoxon Signed Ranks Skor Kemampuan Pembuktian Pernyataan Berkuantor

\begin{tabular}{|l|c|c|c|c|c|c|c|}
\hline & Total & Soal No 1 & Soal No 2 & Soal No 3 & Soal No 4 & Soal No 5 & Soal No 6 \\
\hline Statistik & $-2,69$ & $-1,24$ & 0,00 & 0,66 & $-1,67$ & $-3,07$ & $-3,72$ \\
\hline$p$-value & 0,007 & 0,216 & 1,00 & 0,51 & 0,09 & 0,00 & 0,00 \\
\hline
\end{tabular}

Sementara jika dilihat berdasarkan soal (keunikan pernyataan berkuantor), terdapat perbedaan signifikan kemampuan pembuktian pernyataan berkuantor pada soal no 4, 5 dan 6 . Karena pernyataan pada soal no 4, 5 dan 6 adalah pernyataan berkuantor eksistensial, maka 
dapat dikatakan bahwa calon guru matematika mengalami peningkatan kemampuan pembuktian pernyataan berkuantor eksistensial setelah mengikuti pembelajaran dengan menggunakan matriks enam sel.

Berhasil penelitian di atas, terdapat dua temuan yang menjawab pertanyaan penelitian. Pertama, terdapat perbedaan signifikan rata-rata kemampuan pembuktian pernyataan berkuantor calon guru matematika setelah mengikuti pembelajaran dengan menggunakan matriks enam sel. Temuan ini memberikan justifikasi empiris atas rekomendasi penelitian bawha penggunaan matriks enam sel dapat membantu dalam memahami pernyataan berkuantor (Levenson et al., 2012; Tabach et al., 2012). Temuan penelitian ini juga menunjukkan bahwa pemahaman akan struktur logika dari pernyataan berkuantor (yang terdiri dari unsur kuantor, predikat dan nilai kebenaran/validasi) membantu calon guru dalam mengkonstruksi bukti matematika. Hal ini karena pendekatan matriks enam sel memberikan kerangka dalam memahami struktur logika dari pernyataan berkuantor (Levenson et al., 2012; Tabach et al., 2012; Tamba, 2020). Temuan ini sejajar dengan penelitian sebelumnya yang merekomendasi pentingnya pemahaman akan struktur logika dari pernyataan dalam mengkonstruksi bukti (Dawkins, 2017; Dawkins \& Roh, 2016, 2020; Dubinsky \& Yiparaki, 2001; Piatek-Jimenez, 2010).

Kedua, peningkatan signifikan kemampuan pembuktian pernyataan berkuantor dengan pendekatan matriks enam sel terjadi pada pernyataan berkuantor eksistensial. Artinya, meskipun peningkatan skor kemampuan pembuktian pada pernyataan berkuantor universal, namun peningkatan yang signifikan terjadi pada kemampuan pembuktian pernyataan berkuantor universal. Hal ini dapat disebabkan oleh fenomena siswa, mahasiswa bahkan calon guru matematika cenderung membuktikan pernyataan matematika dengan memberikan bukti general/umum (Tabach, Barkai, et al., 2010; Tabach, Levenson, et al., 2010; Tamba, 2020). Calon guru matematika cenderung melihat bahwa bukti dengan memberikan contoh, dengan bilangan atau dengan verbal tidaklah tepat atau tidak mencukupi (Tabach, Barkai, et al., 2010; Tabach, Levenson, et al., 2010). Padahal tidak semua pernyataan tepat dibuktikan secara umum. Misalnya, pernyataan pada soal no 2 dan 4, tidak tepat dibuktikan secara umum. Pembuktian secara umum akan melahirkan kesalahan karena, predikat tidak selalu benar.

Dengan demikian, berdasarkan hasil penelitian di atas, diperoleh bahwa peningkatan kemampuan pembuktian pernyataan berkuantor dari pre-test ke post-test disebabkan oleh penerapan matriks enam sel. Dengan kata lain, penerapan matriks enam sel berdampak pada peningkatan kemampuan pembuktian pernyataan berkuantor calon guru matematika. Hal ini 
sesuai dengan penelitian sebelumnya mengenai penggunaan matriks enam sel, dimana pemahaman guru dan calon guru mengenai makna dan pendekatan pembuktian dari pernyataan berkuantor ketika menggunakan matriks enam sel berkembang (Levenson et al., 2012; Tabach et al., 2012; Tamba, 2020).

\section{KESIMPULAN}

Berdasarkan hasil penelitian dan diskusi di atas dapat disimpulkan bahwa penggunaan matriks enam sel dalam pembelajaran dapat meningkatkan kemampuan pembuktian pernyataan berkuantor calon guru matematika. Secara khusus, kemampuan pembuktian calon guru matematika meningkat secara signifikan pada pernyataan berkuantor eksistensial.

Penelitian ini memberikan kontribusi pada pengembangan pengetahuan dan penelitian mengenai pembuktian pernyataan berkuantor dalam dua hal. Pertama, penelitian ini memberikan justifikasi empiris kuantitatif atas dampak penggunaan matriks enam sel pada kemampuan pembuktian pernyataan berkuantor. Penelitian sebelumnya masih hanya sekadar mengusulkan dan memberikan justifikasi akan penggunakan matriks enam sel (Levenson et al., 2012; Tabach et al., 2012). Kedua, penelitian ini menunjukkan bahwa kesalahan karena adanya kecenderungan membuktikan semua pernyataan matematika dengan memberikan bukti general dapat diatasi dengan pendekatan matriks enam sel. Dengan demikian, penelitian ini menunjukkan bahwa penggunaan matriks enam sel bermanfaat dalam mengembangkan kemampuan pembuktian pernyataan berkuantor.

Meskipun demikian, penelitian ini membuka pintu untuk penelitian lanjutan. Pada penelitian ini pernyataan berkuantor memuat konsep teori bilangan. Penggunaan matriks enam sel dalam memahami pernyataan berkuantor untuk konten lain dapat menjadi topik yang perlu diteliti.

\section{REFERENSI}

Creswell, J. . (2012). Educational Research: Planning, Conducting, and Evaluating. Quantitative and Qualitative Research, 4nd edition (4th ed.). Boston: Pearson.

Dawkins, P. C. (2017). On the Importance of Set-Based Meanings for Categories and Connectives in Mathematical Logic. International Journal of Research in Undergraduate Mathematics Education, 3(3), 496-522. https://doi.org/10.1007/s40753-017-0055-4

Dawkins, P. C., \& Roh, K. H. (2016). Promoting Metalinguistic and Metamathematical Reasoning in Proof-Oriented Mathematics Courses: a Method and a Framework. International Journal of 
Research in Undergraduate Mathematics Education, 2(2), 197-222. https://doi.org/10.1007/s40753-016-0027-0

Dawkins, P. C., \& Roh, K. H. (2020). Assessing the Influence of Syntax, Semantics, and Pragmatics in Student Interpretation of Multiply Quantified Statements in Mathematics. International Journal of Research in Undergraduate Mathematics Education, 6(1), 145-145. https://doi.org/10.1007/s40753-019-00105-5

De Villiers, M. (2004). Using dynamic geometry to expand mathematics teachers' understanding of proof. International Journal of Mathematical Education in Science and Technology, 35(5), 703724. https://doi.org/10.1080/0020739042000232556

Dubinsky, E., \& Yiparaki, O. (2001). On student understanding of AE and EA quantification. Research in Collegiate Mathematics Education, 4(1), 239-289. https://doi.org/10.1090/cbmath/008/11

Hanna, G., \& de Villiers, M. (2008). ICMI Study 19: Proof and proving in mathematics education. ZDM - International Journal on Mathematics Education, 40(2), 329-336. https://doi.org/10.1007/s11858-008-0073-4

Healy, L., \& Hoyles, C. (2000). A study of proof conceptions in algebra. Journal for Research in Mathematics Education, 31(4), 396-428. https://doi.org/10.2307/749651

Herutomo, R. A. (2019). Kesalahan Mahasiswa dalam Pembuktian Matematik. Jurnal Didaktik Matematika, 6(1), 54-68. https://doi.org/10.24815/jdm.v6i1.13262

Kristianto, E., Mardiyana, \& Saputro, D. R. S. (2019). Analysis of Students' Error in Proving Convergent Sequence using Newman Error Analysis Procedure. Journal of Physics: Conference Series, 1180(1). https://doi.org/10.1088/1742-6596/1180/1/012001

Levenson, E., Tsamir, P., Tirosh, D., Dreyfus, T., Barkai, R., \& Tabach, M. (2012). Focusing on the Interactive Development of Secondary School Teachers' Knowledge of Mathematical Statements. Investigations in Mathematics Learning, 5(2), 44-56. https://doi.org/10.1080/24727466.2012.11790322

Miyazaki, M., Fujita, T., \& Jones, K. (2017). Students' understanding of the structure of deductive proof. Educational Studies in Mathematics, 94(2), 223-239. https://doi.org/10.1007/s10649-0169720-9

Morgan, M. E. (2020). Students' Quantifications, Interpretations, and Negations of Complex Mathematical Statements from Calculus. Unpublish Doctoral Thesis. Arizona. Arizona State University https://www.researchgate.net/publication/343999913_Students'_Quantifications_Interpretations 
Dampak Pendekatan Matriks Enam Sel untuk Meningkatkan Kemampuan Pembuktian Calon Guru Matematika, Kimura

_and_Negations_of_Complex_Mathematical_Statements_from_Calculus

NCTM. (2000). Principles and Standard for School Mathematics. Reston: NCTM.

Ngansop, J. N. (2018). Relevance of Learning Logical Analysis of Mathematical Statements. In G.

Kaiser, H. Forgasz, M. Graven, A. Kuzniak, \& E. S. B. Xu (Eds.), Invited Lectures from the 13th International Congress on Mathematical Education (pp. 441-462). Cham: Springer Open. https://doi.org/10.1007/978-3-319-72170-5_32

Pablo, J., Fuller, M. E., Weber, K., Rhoads, K., \& Samkoff, A. (2012). An assessment model for proof comprehension in undergraduate mathematics. Educational Studies in Mathematics, 79(1), 3-18. https://doi.org/1 0. 1 007/s 1 0649-0 11 -9349-7

Piatek-Jimenez, K. (2010). Students' interpretations of mathematical statements involving quantification. Mathematics Education Research Journal, 22(3), 41-56. https://doi.org/10.1007/BF03219777

Sari, C. K., Waluyo, M., Ainur, C. M., \& Darmaningsih, E. N. (2018). Logical errors on proving theorem. Journal of Physics: Conference Series, 948(1). https://doi.org/10.1088/17426596/948/1/012059

Sellers, M., Hah Roh, K., \& David, E. J. (2017). A comparison of Calculus, Transition-to-Proof, and Advanced Calculus Student quantifications in complex mathematical statements. Conference: 20th Annual Conference on Research in Undergraduate Mathematics Education, 285-297. http://sigmaa.maa.org/rume/RUME20.pdf

Stavrou, S. G. (2014). Common Errors and Misconceptions in Mathematical Proving by Education Undergraduates. Issues in the Undergraduate Mathematics Preparation of School Teachers: The Journal, $\quad l(1), \quad 1-8 . \quad$ http://www.k12prep.math.ttu.edu/journal/1.contentknowledge/stavrou01/article.pdf

Stewart, J. (2012). Calculus: Early Transcendentals (7E ed.). Belmont: Brooks/Cole.

Stylianides, G. J., \& Stylianides, A. J. (2017). Research-based interventions in the area of proof: the past, the present, and the future. Educational Studies in Mathematics, 96(2), 119-127. https://doi.org/10.1007/s10649-017-9782-3

Stylianou, D. A., Blanton, M. L., \& Rotou, O. (2015). Undergraduate Students' Understanding of Proof: Relationships Between Proof Conceptions, Beliefs, and Classroom Experiences with Learning Proof. International Journal of Research in Undergraduate Mathematics Education, 1(1), 91-134. https://doi.org/10.1007/s40753-015-0003-0

Tabach, M., Barkai, R., Tsamir, P., Tirosh, D., Dreyfus, T., \& Levenson, E. (2010). Verbal 
Justification-is it a Proof? Secondary School Teachers' Perceptions. International Journal of Science and Mathematics Education, 8(6), 1071-1090. https://doi.org/10.1007/s10763-0109230-7

Tabach, M., Levenson, E., Barkai, R., Tirosh, D., Tsamir, P., \& Dreyfus, T. (2010). Secondary school teachers' awareness of numerical examples as proof. Research in Mathematics Education, 12(2), 117-131. https://doi.org/10.1080/14794802.2010.496973

Tabach, M., Levenson, E., Barkai, R., Tsamir, P., Tirosh, D., \& Dreyfus, T. (2012). An organizer of mathematical statements for teachers: The six-cell matrix. International Journal of Mathematical Education in Science and Technology, 43(6), 765-777. https://doi.org/10.1080/0020739X.2012.662287

Tamba, K. P. (2020). Analisis Kesalahan pada Materi Kuantifikasi Menggunakan Matriks Enam Sel. Jumlahku: Jurnal Matematika Ilmiah, $\quad 6(2), \quad 1-14$. https://doi.org/https://doi.org/10.33222/jumlahku.v6i2.1053 